\title{
PELAKSANAAN SUPERVISI PENDIDIKAN OLEH KEPALA SEKOLAH TERHADAP GURU
}

\author{
Wedi Julian Alza \\ e-mail : wedijulian1999@gmail.com
}

\begin{abstract}
ABSTRAK
Kegiatan supervisi pendidikan sangat diperlukan oleh guru, karena bagi guru yang bekerja setiap hari di sekolah tidak ada pihak lain yang lebih dekat dan mengetahui dari dalam segala kegiatannya, kecuali Kepala Sekolah. Guru merupakan salah satu faktor penentu rendahnya mutu hasil pendidikan.Dalam rangka pelaksanaan program supervisi pendidikan maka harus mencakup semua komponen yang terkait dan mempengaruhi terhadap keberhasilan program supervisi pendidikan. Keberhasilan tersebut dilihat dari komponen perencanaan, implementasi dan dampak dari program supervisi pendidikan.Kepala Sekolah dalam melaksanakan tugas dan tanggung jawabnya sebagai supervisor secara efektif, maka Kepala Sekolah memiliki kompetensi yaitu kemanusiaan, manajerial, dan teknis. Kesemuanya merupakan satu kesatuan yang tidak dapat dipisahkan.
\end{abstract}

Kata Kunci: Supervisi Pendidikan, Kepala Sekolah, Guru

\section{LATAR BELAKANG}

Dewasa ini pendidikan untuk semua(education forall)akan menjadi dambaan setiap orang.Pendidikan seutuhnya(holisticeducation) akan banyak dibicarakan. Manusia akan sadar bahwa hidup ini membutuhkan belajar, untuk memperoleh pengalaman berarti menemukan kemanusiannya manusia. Orang yang belajar memerlukan bantuan dalam proses pembelajaran.(Yuliana, 2009)Yuliana, L. (2009). PELAKSANAAN SUPERVISI PENDIDIKAN OLEH KEPALA SEKOLAH TERHADAP GURU. Penelitian Ilmu Pendidikan, 02(1), 1-13. Retrieved from https://journal.uny.ac.id/index.php/jpip/article/view/4604/3951

Pembelajaran mendambakan orang yang mampu mendapat bantuan (assisting), mendapat support(supporting) dan diajakuntuktukar menukar (informasi). Menurut UU No.20 Tahun 2003 tentang Sistem Pendidikan Nasional yang merumuskan tujuan pendidikan yang ingin dicapai yaitu mengembangkan kemampuan dan membentuk watak serta peradaban bangsa yang martabat dalam rangka mencerdaskan kehidupan bangsa, bertujuan untuk berkembangnya potensi peserta didik agar menjadi manusia yang beriman dan bertaqwa kepada Tuhan Yang Maha Esa, berakhlak mulia, sehat, berilmu, cakap, kreatif, mandiri, dan menjadi warga Negara yang demokratis serta tanggungjawab.Untuk mencapai tujuan nasional tersebut perlu adanya peningkatan setiap jenis dan jenjang pendidikan. Untuk meningkatkan kualitas proses belajar mengajar guru mempunyai peranan yang sangat penting karena gurulah yang berfungsi secara langsung dalam proses belajar mengajar. 
Kepala sekolah menduduki posisi yang strategis di dalam pencapaian keberhasilan suatu sekolah dan berperan sebagai pemimpin pendidikan, administrator dan supervisor(Udik Budi Wibowo,1994:11). Kepala Sekolah sebagai pemimpin karena mempunyai tugas untuk memimpin staf (guru-guru, pegawai dan pesuruh) untuk membina kerjasama yang harmonis antara anggota staf sehingga dapat membangkitkan semangat, serta motivasi kerja sebagai staf yang dipimpin serta meningkatkan suasana yang kondusif.Kepala sekolah sebagai supervisor pendidikan mempunyai kewajiban membimbing dan membina guru atau staf lainnya. Pembinaan dan bimbingan guru akan berpengaruh besar terhadap kelangsungan dan kelancaran proses belajar mengajar.Tugas kepala sekolah sebagai supervisor tersebut adalah memberi bimbingan, bantuan dan pengawasan dan penilaian pada masalah-maslah yang berhubungan dengan tehnis penyelenggara dan pengembangan pendidikan, pengajaran yang berupa perbaikan program pengajaran dan kegiatan-kegiatan pendidikan pengajaran untuk dapat menciptakan situasi belajar mengajar yang lebih baik (HartatiSukirman1999: 45).

Meskipun dalam rancangan secara teoritik sudah ada pihak yang diharapkan dapat melakukan supervisi terhadap guru yaitu kepala sekolah namun belum dapat terlaksana dengan efektif. Dalam kenyataannya beberapa tahun terakhir ini terdapat kepala sekolah yang belum dapat menjalankan kegiatan supervisi dengan baik bahkan semakin berkurang keefektifannya. Ini diakibatkan beban kepala sekolah terlalu berat. Selain kepala sekolah guru juga mempunyai beban yang berat. Ini diakibatkan juga karena banyaknya bidang studi yang diajarkan oleh guru disekolah sehingga tampak akan sangat sulit mempertemukan keduanya. Oleh karena itu perlu dicari alternative pemecahannya pelaksanaan supervisi dapat berjalan efektif dan efesian.

\section{Landasan Teori}

a. Tujuan dan Fungsi Supervisi Pendidikan

Dalam buku pedoman pelaksanaan supervisi pendidikan (2000:11) disebutkan bahwa tujuan supervisi pendidikan adalah perbaikan dan perkembangan proses belajar mengajar secara total, ini berarti bahwa tujuan supervisi tidak hanya memperbaiki mutu guru, tetapi juga membina pertumbuhan profesi guru dalam arti luas termasuk di dalamnya pengadaan fasilitas-fasilitas, pelayanan, kepemimpinan dan pembinaan humanrelation yang baik kepada semua pihak yang terkait.Soewardji Lazaruth (1991:84) menjelaskan bahwa tujuan dari supervisi klinis yaitu mengembangkan situasi belajar mengajar yang lebih efektif antara lain dengan: 1. Membantu guru agar dapat membantu murid-murid dalam proses belajar mengajar. 2. Membantu guru agar dapat melihat dengan jelas tujuan pendidikan. 3. Membimbing guru agar dapat mengefektifkan penggunaan sumber-sumber belajar. 4. Membantu guru agar dapat mengevaluasi kemajuan belajar murid. 5. Membantu guru agar dapat menjalankan tugasnya dengan perasaan penuh tanggungjawab. 
Menurut pendapat Tim Departemen Pendidikan Kebudayaan Republik Indonesia

b. Tugas dan Tanggung Jawab Kepala Sekolah Sebagai Supervisor

Tugas dan tanggungjawab Kepala Sekolah sebagai supervisor (Hendiyat Soetopo dan

Wasty 1998:42) bertugas mengatur seluruh aspek kurikulum yang berlaku disekolah agar dapat berjalan dengan lancar dan dapat memberikan hasil yang sesuai dengan target yang telah ditentukan.Adapun aspek-aspek kurikulum tersebut,meliputi :

a.Membantu guru-guru dalam merencanakan, melaksanakan dan menilai kegiatan program satuan pelajaran

b.Membantu guru dalam menyusun kegiatan belajar mengajar.

c.Membantu guru dalam menilai proses dan hasil belajar rmengajar

d.Membantu guru dalam menilai hasil belajar siswa

e.Membantu guru dalam menterjemahkan kurikulum kedalam pengajaran

Neagley, sebagaimana dikutip Made Pidarta (1997:67) menulis 10 (sepuluh) tugas supervisor sebagai berikut:

a) Mengembangkan kurikulum

b) Mengorganisasi pengajaran

c) Menyiapkan staf pengajaran

d) Menyiapkan fasilitas belajar

e) Menyiapkanbahan-bahan pelajaran

f) Menyelenggarakan penataran-penataran guru

g) Memberikankonsultasi dan membina anggota staf pengajar

h) Mengkoordinasi layanan terhadap para siswa

i) Mengembangkan hubungan dengan masyarakat

j) Menilai pengajaran

\section{c. Definisi Supervisi}

Pengertian supervisi identik dengan pengawas memang tidaklah merupakan suatu kesalahan yang sangat besar, karena aktivitas mengawasi merupakan bagian kecil dari proses supervisi itu sendiri. Hanya perlu ditegaskan bahwa proses supervisi bukan hanya mengawasi suatu proses pekerjaan saja, tapi meliputi semua kegiatan yang berkaitan dengan pencapaian suatu tujuan, seperti mengkoordinir, membimbing, memotivasi, memimpin, mengoreksi, dan banyak lagi. Secara etimologis supervisi berasal dari bahasa Inggris, to supervise, "mengawasi". Dalam Merriam Webster's Collegiate Dictionary disebutkan bahwa supervisi adalah acritical watchingand directing. Wiles dan Bondi (1986:9) menterjemahkan supervisi sebagai suatu fungsi kepemimpinan umum yang mengkoordinir dan mengelola aktivitas sekolah yang berkaitan dengan pembelajaran. Lebih jauh Piet A. Sehertian mendefinisikan supervisi sebagai suatu usaha memberi layanan kepada guru-guru baik secara individual maupun secara kelompok dalam usaha memperbaiki pengajaran (2000:19). Jelaslah bahwa dalam penerapannya, supervisi merupakan suatu bentuk bimbingan profesional dalam rangka perbaikan suasan belajar mengajar melalui guru-guru.

Supervisi berjalan ketika pertama kali guru direkrut sampai dengan ia dipensiunkan. Berawal dari proses orientasi pegawai baru, guru dikenalkan dengan segala bentuk informasi yang berkaitan dengan kelembagaan, pekerjaan, dan pengembangan diri. Ketika ia sudah melewati 
masa orientasi, masuk ketahapan bekerja yang sesungguhnya, proses supervisi terus dilakukan. Kinerja dan semua sepak-terjang guru dipantau, dinilai, dan tindaklanjuti, dan Dikembangkan sampai akhirnya ia sampai ke fase klimaks pekerjaan, pensiun.

Proses Supervisi

KARIR GURU

Awal

(Rekrutmen)

Akhir karir

(pensiun)

Proses supervisi dalam perjalanan karir guru

d. Tujuan supervisi

Kegiatan supervisi yang dilakukan secara umum bertujuan untuk menjaga kualitas belajar siswa melalui guru dengan cara memberi bimbingan,bantuan dan binaan kepada guru dalam pertumbuhan dan perkembangan karirnya.Dalam tataran praktis,supervisi dilakukan untuk:

1) Menginternalisasikan tujuan pendidikan yang diselenggarakan

2) Mengintroduksi permasalah-permasalahan yang berkaitan dengan siswa

3) Peningkatan etos,produktivitas, efektivitas dan efisiensi kerja

4) Peningkatan profesionalisme dan

5) Demokratisasi

Kelima hal diatas merupakan dasar operasional yang harus dipegang-teguh oleh seorang supervisor dalam melakukan tugasnya.

e. Bentuk Proses Supervisi

Ada lima bentuk proses supervisi yang kita ketahui,yaitu:

1) Supervisi korektif,adalah suatu bentuk bimbingan dan bantuan yang berkaitan dengan upaya perbaikan (koreksi);

2) Supervisi Preventif, kegiatan bimbingan dan bantuan dalam rangka mengantisipasi suatu dampak (bisa kebijakan, ataupun kondisi) agar efektivitas pencapaian tujuan bisa dicapai.

3) Supervisi Konstruktif, adalah suatu kegiatan supervisi yang dimaksudkan untuk 
mengembangkan suatu operasionalisasi pencapaian tujuan pendidikan menjadi lebih baik dan lengkap.

4) Supervisi Kooperatif, adalah bentuk supervisi yang dilakukan bersama antara supervisor dengan guru.Satu sama lain memiliki insiatif untuk memperbaiki proses, meningkatkan kualitas, dan produktivitas.

5) Supervisi Kreatif, bentuk supervisi yang mencoba mengembangkan halyang betul-betul baru, inovatif.

\section{e. Sasaran dan Komponen Supervisi}

Supervisi dengan segala usahanya diarahkan pada pembinaan dan pengembangan aspek-aspek yang terdapat dalam situasi pembelajaran, sehingga akan tercipta suatu situasi yang dapat menunjang pencapaian tujuan pendidikan di sekolah, yang dimaksudkan dengan situasi pembelajaran ialah situasi dimana terjadi proses interaksi antara guru dan murid dalam usaha mencapai tujuan belajar yang telah ditentukan. Tujuan konkret supervisi tersebut menunjukkan tugas-tugas nyata yang harus dilakukan oleh kepala sekolah dalam rangka memperbaiki dan mengembangkan "setting" pembelajaran dalam segala aspeknya, yang berpengaruh kearah yang lebih baik, dan hal tersebut juga menjadi pedoman kegiatan bagi kepala sekolah sebagai seorang supervisor.

Menurut Alfonso (1991:45), "They should be made aware of the criteria by which they will be assessed which should include: class management, relevant subject expertise, appropriate teaching skills, adequacy of lesson preparation, use of resources, understanding of the needs ofpupils and the ability to establish appropriate relationships with pupils and colleagues".

\section{Ada bYuliana, L. (2009). PELAKSANAAN SUPERVISI PENDIDIKAN OLEH KEPALA SEKOLAH TERHADAP GURU. Penelitian Ilmu Pendidikan, 02(1), 1-13. Retrieved from https://journal.uny.ac.id/index.php/jpip/article/view/4604/3951}

eberapa hal yang relevan untuk pengembangan profesional guru, seharusnya guru menyadari tentang kriteria yang akan dinilai atau diamati antara lain: pengelolaan kelas, relevansi ilmu, keahlian mengajar yang sesuai, ketepatan persiapan mengajar, penggunaan sumber-sumber sebagai informasi, pemahanan kebutuhan siswa dan kemampuan menciptakan hubungan yang tepat/sesuai antara siswa dan teman-temannya.

Faktor-Faktor Pendukung Pembelajaran

Sumber:Dasar-dasarSupervisi,SuharsimiArikunto(2004: 32)

Melihat bagan tersebut, terdapat 6 (enam) faktor yang dapat menentukan hasil dari suatu proses pembelajaran,yaitu: 
a) Siswa adalah bahan yang akan diolah dalam suatu proses pembelajaran dengan berbagai tujuan yaitu dikuasainya segenap pengetahuan,kemampuan,keterampilan dan lain-lain oleh siswa setelah proses pembelajaran selesai dilaksanakan.

b) Guru adalah pelaku yang berperan langsung dalam proses pembelajaran mengelola siswa dengan kemampuan profesionalnya.

c) Kurikulum adalah komponen yang mengatur bagaimana guru harus melaksanakan proses pembelajaran dengan bahan, waktu, metode, dan lain-lain serta target yang akan dicapai.

d) Sarana-prasarana adalah berupa hal atau konsep yang membantu untuk memperjelas konsep, dengan sarana dan prasarana yang cukup,sehingga konsep dari guru akan lebih mudah diterima oleh siswa

e) Pengelolaan adalah tindakan dalam melakukan pengelolaan, pengaturan berbagai komponen yang ada, seperti: siswa, sarana yang dibutuhkan, metode atau cara-cara yang paling tepat yang akan dilakukan oleh guru sehingga tercapainya tujuan yang diharapkan.

f) Lingkungan adalah hal-hal yang ada di sekitar pelaksanaan pembelajaran, yang berpengaruh langsung atau tidak langsung terhadap pelaksanaan pembelajaran serta menentukan hasil pembelajaran.

Hal-hal tersebut diatas yang seharusnya menjadi objek atau sasaran supervisi,karena supervisi yang bertujuan menghasilkan mutu pembelajaran. Agar tidak terjadi campur aduk, menurut objek yang harus disupervisi, makaSuharsimi Arikunto (2004: 133) berpendapat,

"supervisi dibagi menjadi 3 (tiga) yaitu: (a) supervisi akademik, yang menitikberatkan pengamatan supervisor pada masalah-masalah akademik, yaitu hal-hal yang langsung berada dalam lingkungan kegiatan pembelajaran pada waktu siswa sedang dalam proses mempelajari sesuatu; (b) supervisi administrasi, yang menitikberatkan pengamatan supervisor pada aspekaspek administrasi yang berfungsi sebagai pendukung dan pelancar terlaksananya pembelajaran; (c) supervisi lembaga, yang menitikberatkan atau menyebarkan objek pengamatan supervisor pada aspek-aspek yang berada di sekolah, jika supervisi akademik dimaksudkan untuk meningkatkan kualitas pembelajaran maka supervisi lembaga dimaksudkan untuk meningkatkan nama baik sekolah atau kinerja sekolah secara keseluruhan”.

\section{g. Prinsip-Prinsip Supervisi}

Piet Sahertian (2000: 20) menyatakan,"masalah yang dihadapi dalam melaksanakan supervisi di lingkungan pendidikan adalah bagaimana cara mengubah pola pikir yang bersifat otokrat dan korektif menjadi sikap yang kreatif. Suatu sikap yang menciptakan situasi dan relasi dimana guru-guru merasa aman dan merasa diterima sebagai subyek yang dapat berkembang sendiri. Untuk itu supervisi harus dilaksanakan berdasarkan data, fakta yang objektif". Sugiyanto (1988: 2) berikut:

"(a) ilmiah, yang mencakup unsur: (1) sistimatis berarti dilaksanakan secara teratur, berencana dan kontinyu, (2) obyektif artinya data yang didapatkan berdasarkan pada observasi nyata bukan tafsiran pribadi, (3) menggunakan instrumen yang dapat memberikan informasi tentang proses belajar mengajar yang sebenarnya, (b) demokratis, (c) kooperatif, (d) konstruktif dan kreatif'. 
Dari prinsip-prinsip supervisi dapat diketahui maknanya bahwa supervisi sebagai suatu kegiatan untuk dilakukan terencana, rutin, berkelanjutan yang dilakukan oleh kepala sekolah, yang menggunakan data dari hasil pergamatan atau observasi nyata menggunakan instrumen yang dapat memberikan informasi yang sebenarnya, sama sekali bukan hasil pelajaran pribadi supervisor. Hubungan antara supervisor bukan bersifat hirarchis yang memposisikan atasan dengan bawahan, namun hubungan kesejajaran, hubungan kemanusiaan yang akrab, saling percaya, yang di supervisi merasa ada sesuatu yang dibutuhkan yaitu bantuan maupun bimbingan yang akan diberikan oleh supervisor. Pembinaan yang diberikan supervisor sebagai sharing of Idea, untuk saling memberi masukan, sehingga supervisi suatu interaksi antara supervisor dan yang disupervisi untuk saling memberikan umpan balik. Langkah pembinaan yang dilakukan supervisor dipercaya mampu dilaksanakan oleh yang di supervisi dan yang di supervisi dengan tidak terpaksa menerima saran supervisor. Hubungan yang demokratis bukan otokratis diharapkan menumbuhkan kreativitas dari para guru.

\section{h. Tehnik-Tehnik Supervisi}

Supervisi merupakan salah satu usaha untuk membantu meningkatkan dan mengembangkan kemampuan guru dalam proses pengajaran. Agar supervisi dapat efektif, supervisor diharapkan memiliki pemahaman untuk memilih teknik-teknik supervisi yang cocok dengan tujuan yang diharapkan. Piet Sahertian (2000: 52) mengemukakan, "Ada beberapa teknik supervisi, antara lain: (a) teknik yang bersifat individual: (1) berkunjung kelas, (2) observasi kelas, (3) percakapan pribadi, (4) intervitasi, (5) penyeleksi berbagai sumber materi untuk mengajar, (6) menilai diri sendiri".

Meskipun dalam rancangan secara teoritik sudah ada pihak yang diharapkan dapat melakukan supervisi terhadap guru yaitu kepala sekolah namun belum dapat terlaksana dengan efektif. Dalam kenyataannya beberapa tahun terakhir ini terdapat kepala sekolah yang belum dapat menjalankan kegiatan supervisi dengan baik bahkan semakin berkurang keefektifannya. Ini diakibatkan beban kepala sekolah terlalu berat. Selain kepala sekolah guru juga mempunyai beban yang berat. Ini diakibatkan juga karena banyaknya bidang studi yang diajarkan oleh guru disekolah sehingga tampak akan sangat sulit mempertemukan keduanya. Oleh karena itu perlu dicari alternative pemecahannya pelaksanaan supervisi dapat berjalan efektif dan efesian. 


\section{PENUTUP}

Kepala sekolah sebagai pemimpin pendidikan mempunyai peran yang sangat besar dalam mengembangkan mutu pendidikan sekolah.Kedudukan kepala sekolah dalam hal ini begitu pentingnya, sehingga ada anggapan tentang "bagaimana" suatu sekolah sangat tergantung pada "bagaimana" kepala sekolahnya.Keberhasilan sekolah adalah keberhasilan kepala sekolah.Kepala Sekolah akan berhasil apabila mereka memahami keberadaan sekolah sebagai oiganisasi yang kompleks dan unik,serta mampu melaksanakan peran kepala sekolah sebagai seorang yang diberi amanat dan tanggung jawab untuk memimpin sekolah.Ditinjau dari struktur organisasi di sekolah,kedudukan guru berada di bawah kepala sekolah.Kedudukan guru adalah sentral,artinya guru menduduki tempat inti dari fungsi sekolah.Guru melakukan tugas mengajar,mendidik,melatih dan membimbing.Kepala sekolah dalam upaya untuk memberdayakan guru, harus mampu menolong para guru dan staf administrasi untuk mencapai tujuan bersama yang telah ditetapkan,memberi kesempatan untuk mengemukakan gagasan,membangkitkan semangat kerja yang tinggi,menciptakan suasana kerja yang menyenangkan,aman dan penuh semangat.Bantuan terhadap guru dalam melaksanakan tugastugas tersebut,dapat dilakukan melalui pelaksanaan supervisi pendidikan.Supervisi pendidikan memberikan tekanan pada proses pembentukan dan pengembangan kemampuan profesional guru,yang dimulai dengan mengadakan perbaikan dalam cara mengajar guru di kelas,dengan cara ini diharapkan siswa dapat belajar dengan baik,sehingga tujuan pengajaran dapat dicapai secara maksimal.Kepala sekolah sebagai supervisor,diharapkan dapat melaksanakan tugasnya dengan melakukan supervisi terhadap proses pembelajaran guru di kelas,dalam rangka meningkatkan kemampuan profesional guru yang tercermin pada kemampuan mengelola proses pembelajaran guru di kelas, yang meliputi: menguasai bahan pelajaran dalam pengertian menguasai bidang studi atau mata pelajaran yang dipegangnya,merencanakan program pembelajaran,melaksanakan dan memimpin/mengelola proses belajar,menilai kemajuan proses pembelajaran. 


\section{DAFTAR PUSTAKA}

Yuliana,L.(2009).Pelaksanaan Supervisi Pendidikan Oleh Kepalasekolah Terhadap Guru.Penelitian Ilmu Pendidikan,02(1),1-13.Retrieved from https://journal.uny.ac.id/index.php/jpip/article/view/4604/3951

Alfonso,R.J.,Firth,G.R.,\&Neville,R.F.(1990).Instructional supervision : behavioral system. Boston: Allyn and Bacon,Inc

Hartati Sukirman,dkk.1999.Administrasi dan Supervisi Pendidikan.FIP IKIP Yogyakarta.

Hendiyat Soetopo dan Wasty. 1998.Kepemimpinan Yang Efektif.Yogyakarta :Gadjah Mada University.

Made Pidarta.1997.Pemikiran tentang Supervisi Pendidikan.Surabaya:Sarana Press.Ngalim

Purwanto.(2003).Administrasi dan supervisi pendidikan.Bandung:PT Remaja Risdakarya.

Piet Sahertian.(2000).Konsep dasar dan tehnik supervisi pendidikan dalam rangka pengembangan sumber daya manusia.Jakarta:Rineka Cipta.

Suharsimi Arikunto.(2004).Dasar-Dasar Supervisi Pendidikan. Jakarta: Rineka Cipta

Udik Budi Wibowo.1994.Profesionalisme Kepala Sekolah. FIP IKIP Yogyakarta

UU No.20 Tahun 2003.Tentang Sistem Pendidikan Nasioanal.Bandung:CitraUmbara. 